JANINA LABOCHA

Jagiellonian University, Cracow

\title{
THE OBJECT OF STUDY OF TEXT LINGUISTICS (TEXTOLOGY)
}

Keywords: text, utterance, discourse, text linguistics, textology, text autonomy, discourse analysis, text as a process

\begin{abstract}
Contemporary text linguistics once again faces the necessity to ask itself a question about the object of its study. The reason for it is the existence of new definitions of text in which text is understood as a process and not as a product, as well as the developing studies of discourse and its social, political, cultural, and ideological determinants. In the present article I attempt to defend the traditional understanding of text as a product, not at the same time negating the necessity of studying communicative and pragmatic processes of discourse determinants. In order to achieve this I use three concepts which, when treated as different aspects of the same phenomenon, may help to grasp the complex object of text linguistics, which is text treated holistically as an integral phenomenon generated in the process of language communication embedded in a broad cultural context. These three concepts which I treat as a unity, and at the same time as three aspects of defining the object of text linguistics are: text, utterance, and discourse.
\end{abstract}

Since the 1970s, i.e. the time when text linguistics began to develop as a separate branch of linguistics, it has been possible to observe the widening of the scope of investigation of this discipline. This has recently been a subject of discussion of various Polish researchers, some of their views are, therefore, worth recalling. Jerzy Bartmińr ski (2005: 47) sees modern textology as a common ground for linguists and literary researchers, which opens a prospect for the integration of the whole philological discipline. In his other works (Bartmiński 1998 as well as Bartmiński, Niebrzegowska-Bartmińska 2009: 12-13) the scholar also advocates a broad scope of textology, indicating that it encompasses all the detailed aspects of text. It may therefore 
be divided into a number of branches: theoretical textology (text theory), descriptive textology, and applied textology (practical). The first branch focuses on studying suprasentential units, which are able to function independently in the process of communication. The aim of the second branch - descriptive textology - is to study the structure, semantics, and pragmatics of concrete texts, and carry out their analysis and interpretation with the help of methods of linguistics and literary studies. The third branch, i.e. applied textology, covers practical operations on texts, their transformations, development, summarising, etc. Here Bartmiński also places editorship and text taxonomy. Bartmiński discusses the name of the discipline as well. As an advocate of the term 'textology' he points out that the name 'text linguistics' separates linguistic studies from the literary or anthropological studies of text (Bartmiński 1998: 19-20). It appears to me, however, that both of these terms may be treated synonymously (Labocha 2008), since, as the history and practice of the studies of this discipline have demonstrated, the linguistic aspect cannot in many cases be separated from the references to the theory of literature, poetics, folk studies, cultural studies, etc. Both terms - text linguistics and textology - imply a broader context than only the strictly linguistics one, i.e. they indicate the interdisciplinary approach to the subject.

Teresa Dobrzyńska (2005: 89) draws attention to the fact that in the recent years the opposition between text understood as a product of communication and text conceived of as a process in the interaction between the sender and the recipient has been sharpened, the process approach drawing attention of the majority of scholars. At this point I would like to add that at present many scholars approach the definition of text understood as a product critically (Duszak 1998: 21; Witosz 2009: 60). Dobrzyńska also points out the fuzzy character of such oppositions and concepts as text, utterance, discourse, as well as the terminological dilemmas connected with it. She also takes note of new tendencies in textology which broaden the scope of the subject matter of this discipline. These are changes connected with the appearance of the concept of the subject and all its human features in the humanities at the cost of the objective interpretations, which separate the product from its creator. In textology this manifests itself through the new understandings of text which consist in the attempts to grasp the strategy of formulating utterances and the schemata developed in a given culture. In the investigation of text this constitutes a shift towards discursive, interactive, pragmatically conditioned and culturally determined phenomena, which means moving into the realms of other disciplines and, at the same time, including many new phenomena in the area of textological studies (Dobrzyńska 2005: 89-92). Anna Duszak (2002: 29-30) states openly the existence of a new paradigm of linguistic thinking, competitive to text linguistics, the latter finding itself at present on the defensive position. The roots of these changes lie in the revaluation which took place in linguistics in the 1980s under the influence of the development of cognitivism. They involved, among others, the rejection of the modular approach towards language, focusing on the mutual infiltration of linguistic and paralinguistic knowledge, and stressing the dynamic aspect of linguistic communication, i.e. processes (strategies and operations) and not artefacts, 
i.e. concrete textual products. The conception of text accepted under the influence of these changes stresses the functionality, interactivity and intertextuality, and it becomes discourse analysis, a new version of text linguistics, because discourse creates, transforms, and expresses relations between man vs. culture and society (Duszak 2002: 31-35). The scholar views the new study of text and discourse as a link between linguistics and the other humanities and social studies. In another work of hers (Duszak 2010) she assumes the point of view of a discipline called critical discourse analysis (CDA), which combines the linguistic analysis of text with the social analysis of the context, i.e. the language external determinants of communication and social life. She investigates the social structure, power relations, systems of values, including ideologies, etc. on the basis of the discursive expression which these processes and social problems find particularly in public social relations. The object of these studies are detailed analyses of written texts, spoken interactions and mediated ones which take into consideration the relations between texts and discourses, communicative styles, the stylistic-rhetorical level of utterance as well as discursive methods and styles of constructing social identity.

Presenting her opinion about the modifications of the methodological foundations of text linguistics which marked the process of conceptualising the object of its studies from text to discourse Bożena Witosz states that

when passing through various methodological 'turns' text linguistics formulated an integrated conception of text - the new proposals did not destroy the earlier findings, and already the first definitions of text which appeared on the Polish grounds announced and, more strictly speaking, determined the direction of further changes (Witosz 2007: 5). [Eng. transl. B. Witosz.]

I share the scholar's point of view, similarly as the opinion that, being under a strong influence of the Prague school of structuralism, Polish textology under the guidance of Maria Renata Mayenowa and her team has developed its firm theoretical foundations (Labocha 2008: 96-102). However, I have a different view than Bożena Witosz as regards the relationship between the concept of discourse and the concept of text. Witosz recognises the dichotomy between describing discourse as a process and text as a product as false, and stresses the fact that the features connected with discourse, i.e. its interactive, processual, and broadly understood situational character, can easily be shifted onto spoken and written texts. The interactive character of the written text is achieved in the process of its construction and interpretation, whereas the sender and the recipient get into interaction not only with text, but through text also with each other. I believe that it is precisely due to this that it appears necessary to introduce, side by side with the concept of text understood as a product of a certain semantic and syntactic structure corresponding to its generic characteristic and pragmatic function, also the concept of utterance which I define as an interactive event embedded in a broadly understood situational context. I treat text and utterance as two different aspects, or better still, two various interpretations of the same cultural phenomenon - of viewing it statically as a product, but at the same dynamically as a process (an interactive event). I perceive utterance as the externalisation of the 
sending and receiving strategy and as a tool of text interpretation or, viewing it differently, as a pragmalinguistic category of text. However, in my opinion the complete description must be supplemented by a third aspect of the cultural phenomenon, which is constituted by text. This is the concept of discourse understood as a norm of the linguistic (or more broadly - communicative) activity in a specific language and cultural community (discourse community, cf. Duszak 1998: 251-260). Discourse as a cultural norm is a factor which regulates individual and social communicative behaviour, including the forms of linguistic activities of a given community. Thanks to these norms and the rules of linguistic and extralinguistic activity corresponding to them we can communicate more easily and effectively, interact with others, and express ourselves in a certain manner and on a given subject. The realisations (actualisations) of these norms and rules are utterances and texts, which we can describe as actualisations of discourse or actualised discourses. The term discourse when used only in the singular number is understood as a cultural norm which regulates linguistic (communicative) behaviour, whereas the term discourse when used also in the plural number, i.e. in the form discourses, may be understood according to the conception presented by me as an expression synonymous with the term utterance. Thus, to sum up, text, utterance, and discourse are various perceptions of the same phenomenon which can be fully described in terms of three aspects, i.e. as a product, event, and norm (Labocha 2008: 73-79; 181-185). Witosz (2009) leans towards the newest conceptualisations which assume the multidimensional, cognitive model of text. She defies the understanding of text as an autonomous product and does not see the need to introduce the concept of utterance to the theory. She perceives text as a phenomenon which is not entitled to semantic autonomy resulting from its deconstextualisation and depersonalisation because it is impossible to think about text as a unit of human communication outside the situational and subjective context. As Witosz (2009: 60) writes (with which I fully concur):

In order for some semiotic structure to be investigated as text at all, it must first be noticed by someone, recognised and interpreted, and thus introduced into a certain communicative context (text itself also bears traces of the reception situation foreseen by the author). [Eng. transl. B. Witosz.]

At this point a certain misunderstanding needs to be clarified. When writing about text autonomy, about the fact that it is a product of the process of communication, I have never assumed that its decontextualisation, separating it from the act of communication, means depriving it of its subjectivity and references to the situation, on the contrary, I have strongly stressed the existence of the pragmalinguistic layer in text which refers the latter to the sending- receiving strategy. It may for instance be evidenced by the following quote from my article "Odbiorca w tekście i wypowiedzi" (“The recipient in text and utterance") (Labocha 1996: 60):

Internal interactivity, i.e. the discursive character of the text, constitutes one of important conditions of its sense. Its lack, e.g. in rough transcripts of speech utterances makes it difficult or even impossible to understand a text. The internal interactivity of text is thus an important criterion of its coherence. [Eng. transl. B. Witosz.] 
A possible answer to the question as to what constitutes the object of text linguistics is that these are speech utterances and written texts which differ not only in terms of the form of their realisation and reception, but predominantly in the way they exist in the universe of linguistic and social communication. Unlike utterance, which in the spoken contact is always formed against the communicative situation, develops linearly in time and is live in the sender-recipient interaction, the written text is formed as a result of often strenuous activities which consist in the use of suitable compositional, stylistic, and linguistic strategies, in agreement with the requirements of the produced genre and the recipient's expectations connected with it. This is always the case when we work on a written text intended for a recipient who will be able to read that text at peace, reflect on its content, also on the content which demands the reconstruction of meanings expressed implicitly and the detection of various traces of the presence of subjective relations and other signals referring the text to the communicative situation of sending or receiving. In other words, at times we track in the written text traces of an utterance included in it, as the most important feature of utterance is its being anchored in the communicative situation. Sometimes, however, we produce a text in writing which is not meant for a quiet "reading to oneself," but which is to be delivered to a certain audience either in the form of "reading aloud" or else in the form of a speech without an overt presence of a piece of paper with the afore-prepared text. Such a text which is to come into existence as a speech utterance in a communicative situation must include distinct signals of the anticipated communicative situation, and thus it should possess, apart from its subject matter, a well-structured pragmalinguistic component which is responsible for the interactive strategy of the utterance on which the effectiveness of the rhetorical behaviour depends. It is rhetorically least advisable to reproduce the prepared text from memory. Between the reproduction and the complete improvisation, which, after all, if it is also to maintain a certain standard, requires earlier consideration, there exists a full range of methods of delivering an afore-prepared text, and this depends on a better or worse retention of the text prepared for delivery in one's head (Labocha 2002, 2006). I call written texts which are intended for delivery recorded texts (Labocha 2004). As a subject of text linguistic research they are linked with an extensive set of issues in the field of rhetorical education and social communication. On the other hand, this question can also be studied as one of the important problems of folklore studies and dialectology, whose subject matter are primarily spoken texts, but analysed and described on the basis of transcripts based on earlier recordings of speech utterances. To sum up, recorded texts are on the one hand texts written with an intention of being delivered, on the other, speech utterances of a certain degree of autonomy (acquiring independence of the communicative situation) recorded with the help of an audio (or video) recording and transferred onto paper or other carrier with the help of graphic signs (various kinds of transcriptions). Their language, style, composition, and generic features are very strongly subordinated to the influence of social factors (sociolinguistic parameters, such as mutual relationships of gender, age, education, profession, social status, etc.). 
The recognition of semantic autonomy as a basic condition for treating a speech utterance or its part as text does not mean its absolute decontextualisation. In agreement with what has been discussed above, each text contains more or less visible traces of utterances, i.e. of a natural communicative process along with its components, which Krystyna Pisarkowa (1978) called the pragmatic background of utterance and described it as a structure consisting of the physical component (tools for and conditions of transmission, the number of participants of the speech act, place, time), the social component (social parameters of the interlocutors, e.g. age, gender, origin, education, profession, social rank as well as the types of relations between them) and the substance-related component (topics, their generic membership and characteristics, e.g. autobiography, family, professional and social life, services, etc.). To these components Pisarkowa added the inherent factor, i.e. the structure of the text itself, for which the direct background is the sender's intention and the function of the speech act, the sender's intention and the degree of importance of the act (according to the sender), the sender's intention and the degree of the act openness, as well as its purpose (for an official, public or only unofficial situation). However, a primary element of the inherent factor is the language substance, which varies depending on whether we deal with a written or a spoken text.

The autonomy of the written text results form the very act of its formation. As Janusz Lalewicz (1975: 53) wrote, the utterance is semantically independent of the context if its interpretation does not require the knowledge of this context. It needs to be stressed that here we are concerned with the interpretation and text understanding transmitted by an utterance, and not the lack of any traces of the context (understood as a communicative situation) in this text. The speech utterance, especially one which appears in an official situation, in a careful variety of speech, is adapted by the sender for a possible repetition as a result of endeavours to free it from any relations with the consituation, and at the same time to its exceeding the temporary limitations of space and time (Pisarek 1994: 17). Of course, autonomous text, written or recorded (primarily spoken) enters into a "dialogue" with other texts, i.e. into intertextual relations. The recorded text gets detached from the situation of its origin and opens itself to an infinite number of readings and interpretations, that is, it gains autonomy, contrary to utterance, which is always immersed in the communicative situation, and its extraction from it makes it semantically incomplete. It is only due to suitable editorial activities that it is possible for a part of an utterance which qualifies for decontextualisation to gain semantic autonomy as a recorded text (an edited part of a speech utterance which, due to its having created its own text world has been able to get detached from the communicative situation), e.g. a gossip, self-presentation, an account of some event. ${ }^{1}$

Critical comments concerning such a conception were put forward by Bożena Witosz (2009: 60). I wish to add, however, that the understanding of text I have postulated should be considered in juxtaposition with the two remaining concepts: of utterance and discourse (Labocha 2008). What is crucial for me is that in isolation from them it is not possible to speak about meeting the definitional requirements of text in the process of language communication. 
Text autonomy has a scalar character, its degree depends on various intratextual and extratextual factors, the author's and the editor's moves, the presence of metatext and paratext in it (Genette 1992, Loewe 2007), i.e. texts and utterances parallel to the basic text: titles, introductions, prefaces, dedications, epilogues, mottoes, footnotes, editorial notes, commentaries, etc. These issues already constitute a subject of studies and description in the field of text linguistics. Text autonomy is, however, primarily evidenced by the textual world created in it, to use Ryszard Nycz's term (2000). Admittedly, as poststructuralists claim, text meaning depends on the changeable and open context, however, the multiplicity of interpretations does not deny the existence of a text world, which is defined in greater detail and completed by the recipient in the process of reading. Deconstructionism questions the conviction about the existence of a uniformed meaning, as there is more than one way of interpreting a text. This particularly concerns the poetic text and its complex multi-faceted structure of meaning, which compels plurality of interpretations irrespective of the reader's philosophical and interpretative basis. The traditional model of text is characterised by three main properties: 1. autonomy understood as independence of the pragmatic context (the author's intention, communicative situation) and of the historical and ideological one, 2. objectivity, i.e. the recognition of the semantic structure as its stable component, irrespective of the interpretation; 3. unity understood as an internally coherent whole (Nycz 2000: 118). The Polish model, represented by Mayenowa's school (1971, 1974, 1976), verifies these three properties by means of stressing the role of the recipient both in the completion of the semantic structure of the text and in the reconstruction of its coherence. From the point of view of the text recipient text is a coherent informative whole if s/he knows what it speaks about. It concerns not only the reconstruction of meanings together with the presuppositions and implications which are inherent in the text, but also the pragmatic sense lying at its foundation. In reference to Mayenowa's views it is possible to say that text autonomy does not result from its decontextualisation, but from the existence of a context whose influence and causative power allow for the creation of a semantic structure independent of communicative factors, but in such a way that it should contain spaces for a pragmalinguistic content to be filled each time the text is read, interpreted, modified, reconstructed, etc. A model opposite to the traditional one is the deconstructive model (Nycz 2000: 119-120), which treats text as non-autonomous, deprived of an objective semantic structure and unity. Text in itself does not exist, and therefore no interpretation can be adequate and correct as it is not possible to talk about interpreting something which has no objective existence (prior to and independent of interpretation). According to the main representative of deconstruction, the French philosopher Jacques Derrida, it is in no way possible to restrict the number of contexts of a given text, i.e. to deplete the number of its meanings. Interpretation always remains incomplete because there does not exist the ultimate, final context of a text (Burzyńska, Markowski 2006: 378-379).

According to Nycz (2000: 191-196), when applied to the literature of the recent decades the term postmodernism forms a meaningful correlation with poststructuralism within the bounds of the reflection of literary studies through the critical 
attitude towards both the formalist-structuralist tradition and the positivist-sociological heritage. The centre of attention are currently the problems of pragmatic determinants and external references of the literary text. The ultimate meaning of a text is decided by its pragmatic frames which combine the utterance with other forms of discursive practices and with the historical, social and ideological contexts in which it is inscribed. The role of immanent, structural regularities is diminished or they are ignored.

The postmodernist perception of the literary text is a reason why contemporary textology witnesses the formation of tendencies to treat each text, not only a poetic (literary) one, as a process, and thus as something indefinable in its dynamics, developing within social interaction and in strict dependency on the communicative situation, as well as the intertextual context tinted ideologically, historically, socially, politically, etc. This has its advantages, as it broadens the research horizon, and allows one to take up studies on the problems of social, medial, political, etc. communication, within the framework of the so called discourse analysis (Duszak 2010) or a broadly understood discourse stylistics (Witosz 2009), which are characterised by a holistic approach to text. On the other hand, it creates a danger of making the subject of text linguistics completely fuzzy. And the subject is, after all, text and not social communication in all its contemporary dimensions: political, social, economic, biological, etc. It is not ideology or a broadly understood mediality, but textual testimonies of these phenomena. It is text as a document, as a part of text archives of the discourses existing in our times, the discourses expressed by means of language. It is finally text as a representative of a concrete genre, style, and language variety.

The comprehensive approach towards text, its holistic treatment are an important postulate of contemporary textology. However, this theoretical assumption cannot be implemented in research practice in any other way but in stages (Bartmiński, Niebrzegowska-Bartmińska 2009: 348-357). We thus return to the problem of the levels of text description, as it was indicated in the works of a Czech linguist, František Daneš $(1970,1974,1976,1985)$. At this point it is worth referring to the comments of Sambor Grucza (2009: 95-99), who views the widening of the scope of text linguistics as a positive phenomenon, he, however, has a negative attitude towards the shifting of the centre of gravity of its interests onto new elements of its subject matter just recently included in it, which is at the same time accompanied by recognising the former scopes of the field as less important or completely unimportant. And thus, for instance, the shift of the centre of gravity onto the pragmatic and cognitive aspects has resulted, among others, in negligence of the problem of the description of the general essence of textuality and a detailed one for each text genre, which is an important research task of text linguistics. I would add one more aspect here, namely the opposition between writing and speech in the textological interpretation. These two varieties of language generate specific systems and forms of textual behaviour, especially in contemporary public, medial, and electronic communication. To conclude, it is worth quoting the words of Paul Ricoeur (1976: 25), which may constitute the starting point for further consideration: 
What happens in writing is the full manifestation of something that is in a virtual state, something nascent and inchoate, in living speech, namely the detachment of meaning from the event.

I also treat these words as a summary of the reflections concerning text autonomy presented in this article.

\section{References}

Bartmiński J. 1998. Tekst jako przedmiot tekstologii lingwistycznej. - Bartmiński J., Boniecka B. (eds.) Tekst. Problemy teoretyczne. Lublin: 9-25.

Bartmiński J. 2005. Pytania o przedmiot językoznawstwa: pojęcia językowego obrazu świata i tekstu w perspektywie polonistyki integralnej. - Czermińska M., Gajda S., Kłosiński K., Legeżyńska A., Makowiecki A.Z., Nycz R. (eds.) Polonistyka w przebudowie. Literaturoznawstwo - wiedza o języku - wiedza o kulturze - edukacja. [Zjazd Polonistów Kraków, 22-25 września 2004]. Kraków: 39-49.

Bartmiński J., Niebrzegowska-Bartmińska S. 2009. Tekstologia. Warszawa.

Burzyńska A., Markowski M.P. 2006. Teorie literatury XX wieku. Podręcznik. Kraków.

Daneš F. 1970. Zur linguistischen Analyse der Textstruktur. - Folia Linguistica IV: 72-78.

Daneš F. 1974. Semantyczna i tematyczna struktura zdania i tekstu. - Mayenowa M.R. (ed.) Tekst i język. Problemy semantyczne. Wrocław, Warszawa, Kraków, Gdańsk: 23-40.

Daneš F. 1976. Zur semantischen und thematischen Struktur des Kommunikats. - Daneš F., Viehweger D. (eds.) Probleme der Textgrammatik. Studia Grammatica. [vol. XI]. Berlin: 29-40.

Daneš F. 1985. Věta a text. Praha.

Dobrzyńska T. 2005. Badanie struktury tekstu i form gatunkowych wypowiedzi jako klucz do opisu kultury i rozumienia literatury. - Czermińska M., Gajda S., Kłosiński K., Legeżynska A., Makowiecki A.Z., Nycz R. (eds.) Polonistyka w przebudowie. Literaturoznawstwo - wiedza o języku - wiedza o kulturze - edukacja. [Zjazd Polonistów Kraków, 22-25 września 2004]. Kraków: 87-96.

Duszak A. 1998. Tekst, dyskurs, komunikacja międzykulturowa. Warszawa.

Duszak A. 2002. Dokąd zmierza tzw. lingwistyka tekstu? - Krążyńska Z., Zagórski Z. (eds.) Poznańskie Spotkania Językoznawcze. [vol. IX]. Poznań: 29-37.

Duszak A. 2010. Styl jako kategoria krytycznej analizy dyskursu. - Bogołębska B., Worsowicz M. (eds.) Styl - dyskurs - media. Łódź: 33-43.

Genette G. 1992. Palimpsesty. Literatura drugiego stopnia. - Markiewicz H. (ed.) Wspótczesna teoria badań literackich za granicą. [vol. 4]. Kraków.

Grucza S. 2009. Lingwistyka tekstu - jej przedmiot i cele cząstkowe badań. - Bilut-Homplewicz Z., Czachur W., Smykała M. (eds.) Lingwistyka tekstu w Polsce i w Niemczech. Pojęcia, problemy, perspektywy. Wrocław: 95-107.

Labocha J. 1996. Odbiorca w tekście i wypowiedzi. - Gajda S., Balowski M. (eds.) Styl a tekst. Opole: $55-60$.

Labocha J. 2002. Spójność wypowiedzi retorycznej. - Krążyńska Z., Zagórski Z. (eds.) Poznańskie Spotkania Językoznawcze. [vol. IX]. Poznań: 93-99.

Labocha J. 2004. Tekst pisany - tekst zapisany. Biuletyn Polskiego Towarzystwa Językoznawczego LX: 5-10.

Labocha J. 2006. Tekst zapisany jako podstawa przemówienia. - Witosz B. (ed.) Style konwersacyjne. Katowice: 201-205. 
Labocha J. 2008. Tekst, wypowiedź, dyskurs w procesie komunikacji językowej. Kraków.

Lalewicz J. 1975. Komunikacja językowa i literatura. Wrocław, Warszawa, Kraków, Gdańsk. Loewe I. 2007. Gatunki paratekstowe w komunikacji medialnej. Katowice.

Mayenowa M.R. 1971. Spójność tekstu a postawa odbiorcy. - Mayenowa M.R. (ed.) O spójności tekstu. Wrocław, Warszawa, Kraków, Gdańsk: 189-205.

Mayenowa M.R. 1974. Poetyka teoretyczna. Zagadnienia języka. Wrocław, Warszawa, Kraków, Gdańsk.

Mayenowa M.R. 1976. Posłowie: Inwentarz pytań teorii tekstu. - Mayenowa M.R. (ed.) Semantyka tekstu i języka. Wrocław, Warszawa, Kraków, Gdańsk: 293-294.

Nycz R. 2000. Tekstowy świat. Poststrukturalizm a wiedza o literaturze. Kraków.

Pisarek W. 1994. Polszczyzna oficjalna na tle innych jej odmian. - Kurzowa Z., Śliwiński W. (eds.) Współczesna polszczyzna mówiona w odmianie opracowanej (oficjalnej). Kraków: $13-21$.

Pisarkowa K. 1978. Zdanie mówione a rola kontekstu. - Skubalanka T., Grabias S., Mazur J., Pisarkowa K. (eds.) Studia nad składnia polszczyzny mówionej. Wrocław, Warszawa, Kraków, Gdańsk: 7-20.

Ricoeur P. 1976. Interpretation theory: discourse and the surplus of meaning. Fort Worth.

Witosz B. 2007. Lingwistyka tekstu - stan aktualny i perspektywy. - Poradnik Jęzkowy 7: 4-18.

Witosz B. 2009. Dyskurs i stylistyka. Katowice. 